\title{
Analisis Penerapan Metode Lossy Pada Kompresi Citra Steganografi
}

\author{
Abdul Sani Sembiring \\ STMIK Budi Darma Medan, JI. SM.Raja No.338 Sp.Limun Medan, Sumut, Indonesia \\ www.stmik-budidarma.ac.id // E-mail : gurkiy@gmail.com
}

\begin{abstract}
The internet has become a very important part of communication development in the world. Exchange of information over the internet has many advantages compared to other communication media, especially in terms of speed. But information sent via the internet, security cannot be accounted for. Tapping on confidential information, very often occurs in this communication media. Channels used by the internet are generally not safe channels.

By using the lossy compression method, compression can only be applied to images that have similarities to themselves (self similiarity) so that the size of the image gets smaller and saves storage space and accelerates the sending of the image using internet media.
\end{abstract}

\section{Kata kunci: Lossy, Citra, Kompresi, Steganografi, BPCS}

\section{PENDAHULUAN}

Kompresi citra adalah aplikasi kompresi data yang dilakukan terhadap citra digital dengan tujuan untuk mengurangi redundansi dari data-data yang terdapat dalam citra sehingga dapat disimpan dan ditransmisikan secara efisien. Pada pemampatan dengan metode Lossy hanya bisa diterapkan untuk citra yang memiliki kemiripan dengan dirinya sendiri (self similiarity).

Steganografi adalah suatu seni kuno menyampaikan pesan dengan cara rahasia, sehingga hanya penerima yang mengetahui. Steganografi membutuhkan dua properti, yaitu media penampung dan data rahasia yang akan disembunyikan.

Citra menjadi objek kompresi dan steganografi oleh penulis, dikarenakan kompresi dan steganografi sama-sama dapat menggunakan objek citra yang diangkat penulis. Walaupun sebenarnya banyak objek lain selain citra yang dapat diterapkan pada kompresi dan steganografi.

\section{LANDASAN TEORI}

\subsection{Kompresi}

Kompresi citra adalah aplikasi kompresi data yang dilakukan terhadap citra digital dengan tujuan untuk mengurangi redudansi dari data-data yang terdapat dalam citra sehingga dapat disimpan atau ditransmisikan secara efisien.

Kompresi citra memiliki manfaat yang besar dalam industri multimedia saat ini. Berikut manfaat yang di dapat kompresi adalah:
1. Pengiriman data (data transmisson) pada saluran komunikasi data

Citra yang telah dikompres dapat dikirim dengan waktu yang lebih singkat dibandingkan dengan citra yang tidak dikompres. Contoh aplikasi gambar lewat fax, pengiriman data medis, pengiriman gambar via telepon genggam, download gambar dari internet, dan sebagainya.

2. Penyimpanan data (data storing) di dalam media sekunder (storage)

Citra yang telah dikompres membutuhkan ruang memori di dalam media storange yang lebih sedikit dibandingkan basis data gambar, office automation, vidieo storange (seperti vidieo compact disc) dan lain-lain.

Kompresi citra bertujuan untuk meminimalkan jumlah bit yang diperlukan untuk merepresentasikan citra. Apabila sebuah foto berwarna berukuran 3 inci x 4 inci diubah ke bentuk digital dengan tingkat resolusi sebesar 500 dot per inch (dpi), maka diperlukan $3 \times 4 \times 500 \times 500=3.000 .000$ dot ( pixel). Setiap pixel terdiri dari 3 byte dimana masing-masing byte merepresentasikan warna merah, hijau, dan biru. sehingga citra digital tersebut memerlukan volume penyimpanan sebesar $3.000 .000 \times 3$ byte $+1080=9.001 .080$ byte setelah ditambahkan jumlah byte yang diperlukan untuk menyimpan format (header) citra.

Kompresi citra dikembangkan untuk memudahkan penyimpanan dan pengiriman citra. Teknik kompresi yang ada sekarang memungkinkan citra dikompresi sehingga ukurannya menjadi jauh lebih kecil daripada 
ukuran asli. Ada dua tipe utama kompresi data, yaitu kompresi tipe lossless dan kompresi tipe lossy. Kompresi tipe lossy adalah kompresi dimana terdapat data yang hilang selama proses kompresi. Akibatnya kualitas data yang dihasilkan jauh lebih rendah daripada kualitas data asli. Sementara itu, kompresi tipe lossless tidak menghilangkan informasi setelah proses kompresi terjadi, akibatnya kualitas citra hasil kompresi tidak menurun. Namun demikian, rasio kompresi yang digunakan untuk kompresi tipe lossless lebih kecil daripada rasio kompresi pada kompresi tipe lossy.

Parameter-parameter citra yang penting dalam proses kompresi diantaranya adalah sebagai berikut

1. Resolusi

Resolusi citra menyatakan ukuran panjang kali lebar dari sebuah citra. Resolusi citra biasanya dinyatakan dalam satuan pixel. Semakin tinggi resolusi sebuah citra, semakin baik kualitas citra tersebut. Namun, tingginya resolusi menyebabkan semakin banyaknya jumlah bit yang diperlukan untuk menyimpan dan mentransmisikan data citra tersebut.

2. Kedalaman Bit

Kedalaman bit menyatakan jumlah bit yang dipelukan untuk mrepresentasikan tiap pixel citra pada sebuah frame. Kedalaman bit biasanya dinyatakan dalam satuan bit/ pixel. Semakin banyak jumlah bit yang digunakan untuk merepresentasikan sebuah citra, maka semakin baik kualitas citra tersebut.

3. Konsep Redundansi

Redundansi merupakan suatu keadaan dimana representasi suatu elemen data tidak bernilai signifikan dalam merepresentasikan keseluruhan data. Keadaan ini menyebabkan data keseluruhan dapat direpresentasikan secara lebih kompak dengan cara menghilangkan representasi dari sebuah elemen data yang redundan. Redundansi yang terdapat pada citra statik adalah redundansi spasial.

Metode kompresi citra berdasarkan redundansi spasial diantaranya adalah sebagai berikut :

a. Subsampling

Subsampling merupakan metode kompresi dengan mengurangi jumlah pixel yang diperlukan untuk merepresentasikan suatu citra. Subsampling dapat dilakukan dengan dua cara. Cara pertama adalah mengambil pixel - pixel tertentu dari citra, misal pixel - pixel pada baris dan kolom saja. Cara kedua adalah dengan mengambil rata-rata dari kelompok pixel dan menggunakan nilai tersebut sebagai ganti nilai kelompok pixel ini. Cara ini lebih kompleks, tetapi menghasilkan kualitas yang lebih baik. Subsampling sebanding dengan pengurangan resolusi

b. Pengurangan kedalaman bit

Metode ini dilakukan dengan mengurangi jumlah bit yang digunakan untuk mrerepresentasikan suatu pixel. Misalnya dengan mengurangi kedalaman bit dari 16 bit/ pixel menjadi 8 bit/ pixel. Metode ini mengurangi kualitas citra

c. Transformation Coding

Transformation coding merupakan transformasi data dari domain ruang ke domain frekuensi. Cara ini menghasilkan data yang lebih mudah diproses untuk kompresi lebih lanjut. Transformasi yang populer digunakan antara lain Discrete Cosine Transform (DCT) yang diadopsi dalam standar kompresi JPEG dan Discrete Wavelet Transform (DWT) yang digunakan dalam kompresi JPEG 2000.

Kriteria yang digunakan untuk mengukur pemampatan citra adalah :

1. Waktu kompresi dan waktu dekompresi

Proses kompresi merupakan proses mengodekan citra (encode) sehingga diperoleh citra dengan representasi kebutuhan memori yang minimum. Proses dekompresi adalah proses untuk menguraikan citra yang dimampatkan untuk dikembalikan lagi (decoding) menjadi citra yang tidak mampat.

2. Kebutuhan memori

Metode kompresi yang baik adalah metode kompresi yang mampu mengompresi file citra menjadi file yang berukuran paling minimal. Biasanya semakin besar persentase pemampatan, semakin kecil kebutuhan memori yang diperlukan sehingga kualitas citra makin berkurang. Dan sebaliknya, semakin kecil persentase citra yang dimampatkan, semakin bagus kualitas hasil pemampatan tersebut.

3. Kualitas Pemampatan

Metode kompresi yang baik adalah metode kompresi yang mampu mengembalikan citra hasil kompresi menjadi citra semula tanpa kehilangan informasi apa pun. Semakin berkualitas hasil pemampatan, semakin besar memori yang dibutuhkan.

4. Format Keluaran 
Format citra hasil pemampatan yang baik adalah yang cocok dengan kebutuhan pengiriman dan penyimpanan data.

\subsection{Citra Digital}

\section{Konsep Citra Digital}

Citra digital adalah citra yang dapat diolah oleh komputer. Sebuah citra digital menyimpan data berupa bit yang dapat dimengerti oleh manusia dengan visualisasi bit tersebut pada kanvas menjadi gambar. Pengolahan yang dapat dilakukan terhadap citra digital antara lain adalah menampilkan bentuk gambar, melakukan perubahan terhadap gambar (image editing), dan pencetakan citra digital ke atas media berupa kertas.

Citra digital terdiri dari pixel-pixel berukuran kecil yang membentuk sebuah bentuk gambar yang dapat dilihat oleh mata manusia. Kepadatan pixel - pixel yang ada dalam gambar ini disebut dengan resolusi. Semakin besar resolusi sebuah citra digital maka kualitas gambar dari citra digital tersebut semakin baik. Gambar 1 menunjukkan pixelpixel yang ada dalam sebuah gambar.
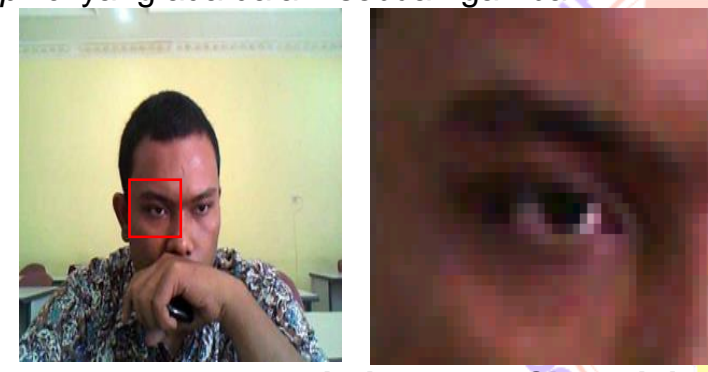

Gambar 1 : llustrasi Pixel pada Citra Digital

\section{Warna pada Citra Digital}

Citra digital memiliki beberapa jenis cara pewarnaan. Tiap jenis pewarnaan ini memiliki karakteristik masing-masing. Jenis pewarnaan ini memberikan pengaruh pada citra digital sehingga memiliki jumlah warna yang berbeda (perbedaan kualitas warna) dan pengaruh pada ukuran dokumen. Berikut adalah jenisjenis pewarnaan pada citra digital.

1. Hitam dan Putih (Duotone)

Pada citra digital dengan pewarnaan duotone, warna pada pixel hanya memiliki 2 kemungkinan warna, pada umumnya hitamputih. Duotone ini disebut juga dengan warna 1-bit, karena setiap pixel hanya membutuhkan 1 bit untuk menyimpan warna pixel tersebut. Selain itu duotone juga dikenal dengan sebutan monochrome.

Dengan penggunaan warna 1-bit, maka kualitas gambar pada citra digital tidak begitu bagus. Untuk sebuah gambar yang sederhana penggunaan warna 1-bit sangat sederhana karena memiliki ukuran file yang jauh lebih kecil dibandingkan dengan penggunaan sistem warna lainnya, namun pada sebuah citra digital yang merupakan foto, maka gambar foto tersebut akan mengalami pengurangan kualitas yang signifikan dengan penggunaan warna 1-bit.

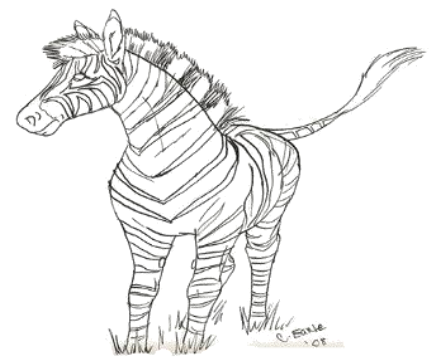

\section{Gambar 2 : Warna I 8-bit (256 colors warna)}

Sumber : http://color-meclub.deviantart.com/art/Zebra-lineart-99491504

\section{Hitam Putih dan Abu-Abu ( Grayscale )}

Citra digital dengan pewarnaan grayscale tidak memiliki warna yang terlalu banyak. Pada grayscale, warna yang tersedia hanyalah warna-warna yang ada diantara hitam dan putih, meliputi warna abu-abu yang beragam. Namun kualitas yang dihasilkan warna grayscale ini jauh lebih baik dibandingkan dengan duotone yang hanya terdiri dari hitam dan putih. Pada gambar dengan pewarnaan grayscale, perubahan warna antara satu pixel ke pixel lainnya tidak terlihat sangat signifikan sehingga gambar dapat lebih mudah dicerna oleh mata manusia. Jika pada duotone bit yang dimiliki tiap pixel hanya 1 , maka pada grayscale setiap pixel direpresentasikan dalam 8 bit data. Dengan penggunaan warna 8-bit ini maka ukuran dokumennya pun otomatis menjadi semakin besar dibandingkan dengan warna 1-bit.

\section{Gambar 3 : Warna Grayscale}

Sumber : http://www.eclipse.org/articles/ArticleUI-Guidelines/Index.html

\section{Citra Digital Berwarna}

Citra digital berwarna membutuhkan ukuran dokumen yang relatif besar jika dibandingkan dengan format duotone dan grayscale karena kebutuhan penyimpanan bit yang lebih banyak. Pada citra digital berwarna, pada umumnya warna pixel yang ada terbentuk dari 3 nilai komponen warna, yaitu merah, hijau dan biru $(R G B)$. 


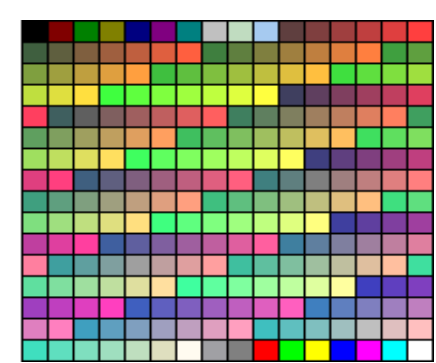

\section{Gambar 4 : Warna I 8-bit (256 colors warna) Sumber : \\ http://www.eclipse.org/articles/Article-UI- Guidelines/lndex.html}
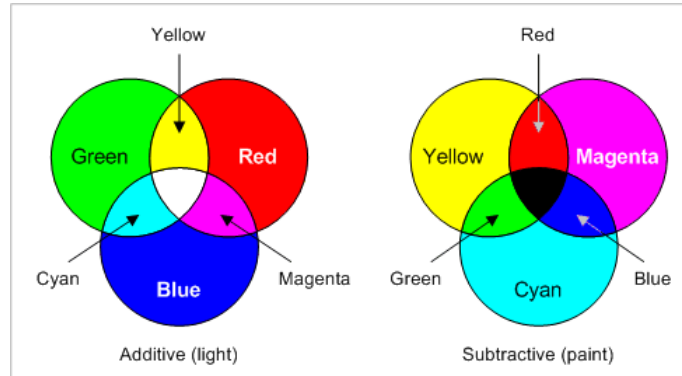

Additive and subtractive color combinations

Gambar 5 : Warna RGB 32-bit

Sumber:

http://www.infofotografi.com/blog/2014/06/dyna mic-range-bit-depth-dan-color-depth-dalamsensor-kamera-digital/

Jumlah bit yang digunakan tiap pixel pada citra digital berwarna beraneka ragam, mulai dari 8-bit hingga 32-bit. Semakin besar jumlah bit yang digunakan, maka semakin tinggi kualitas warna dari gambar tersebut.

\section{a. 8-bit (256 warna)}

Penggunaan 8-bit data untuk tiap pixel ini mirip dengan pada pewarnaan grayscale, namun 256 warna yang ditentukan tidak semuanya berwarna abu-abu. Kualitas warna dengan pewarnaan 8-bit atau yang lebih dikenal dengan sebutan 256 colors ini belum terlalu baik. Gambar 2.3 menunjukkan proses menampilkan warna pixel pada 256 colors.

b. Indexed color

Pada indexed color, jumlah bit yang digunakan 8-bit dan jumlah warnanya pun 256. Namun 256 warna tersebut dapat didefinisikan dalam citra digital. Dengan mendefinisikan tabel warna yang berisi 256 warna tersebut, kualitas warna gambar dapat meningkat. Gambar 2.4 menunjukkan contoh penggunaan table warna untuk meningkatkan kualitas warna pada indexed color.

c. Red Green Blue (RGB)
Dengan menggunakan pewarnaan ini, bit-bit pembentuk pixel merupakan perwakilan dari setiap elemen pembentuk warna yaitu merah, hijau dan biru. Jumlah bit yang digunakan pada warna $R G B$ sangat beragam, diantaranya adalah 16-bit, 24-bit dan 32bit (true color). Semakin banyak jumlah bit yang merepresentasikan warna, maka kualitas warna tersebut semakin baik. Pada warna 32-bit, artinya ada 8-bit yang merepresentasikan warna merah, 8-bit untuk warna biru dan 8-bit untuk warna hijau. Gambar 6. menunjukkan bagaimana gambar $R G B$ dengan 24-bit ditampilkan.

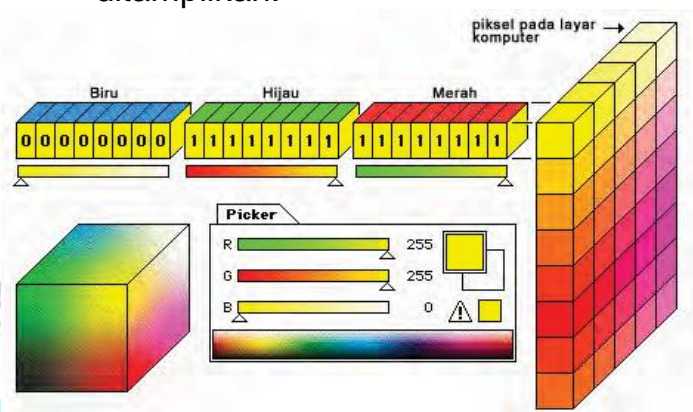

Gambar 6 : Proses Menampilkan Gambar dengan Warna 24-bit

\subsection{Steganografi}

Tujuan dari steganografi adalah merahasiakan atau menyembunyikan keberadaan dari suatu pesan tersembunyi atau sebuah informasi. Dalam prakteknya diselesaikan dengan membuat perubahan tipis terhadap digital lain yang isinya tidak akan menarik perhatian dari penyerang potensial, sebagai contoh sebuah gambar yang terlihat tidak berbahaya. Perubahan ini tergantung kunci (sama pada kriptografi) dan pesan untuk disembunyikan. Orang yang menerima gambar kemudian dapat menyimpulkan informasi terselubung dengan cara mengganti kunci yang benar ke dalam algoritma yang digunakan.

Pada steganografi cara ini bermanfaat jika digunakan pada cara steganografi komputer karena banyak format digital yang dapat dijadikan media untuk menyembunyikan pesan. Format yang umum dilakukan antara lain :

1. Format image : bitmap ( bmp ), GIF, pcx, JPEG, dll

2. Format audio: wav, voc, $m p 3$, dll

3. Format lain : txt, $h t m l$, pdf, dll.

\subsection{Metode Lossy}

Lossy kompresi adalah suatu metode untuk mengkompresi data dan mendekompresinya, data yang diperoleh mungkin 
berbeda dari yang aslinya tetapi cukup dekat perbedaaanya. Lossy kompresi ini paling sering digunakan untuk kompres data multimedia (Audieo, gambar diam). Sebaliknya, kompresi lossless diperlukan untuk data teks dan file, seperti catatan bank, artikel teks dll.

Format kompresi lossy mengalami generation lossy yaitu jika melakukan berulang kali kompresi dan dekompresi file akan menyebabkan kehilangan kualitas secara progresif. hal ini berbeda dengan kompresi data lossless. ketika pengguna yang menerima file terkompresi secara lossy (misalnya untuk mengurangi waktu download) file yang diambil dapat sedikit berbeda dari yang asli dilevel bit ketika tidak dapat dibedakan oleh mata dan telinga manusia untuk tujuan paling praktis. Metode ini menghasilkan ratio kompresi yang lebih besar daripada metode lossless. Misal terdapat image asli berukuran 12,249 bytes, kemudian dilakukan kompresi dengan JPEG kualitas 30 dan berukuran 1,869 bytes berarti image tersebut $85 \%$ lebih kecil dan ratio kompresi $15 \%$. Contoh metode lossy adalah metode CS\&Q (coarser sampling and/or quantization), JPEG, dan MPEG.

Ada dua skema dasar lossy kompresi :

1. Lossy transform codec, sampel suara atau gambar yang diambil, di potong kesegmen kecil, diubah menjadi ruang basis yang baru, dan kuantisasi. hasil nilai kuantisasi menjadi entropy coded

2. Lossy predictive codec, sebelum dan/atau sesudahnya data di-decode digunakan untuk memprediksi sampel suara dan frame picture saat ini. kesalahan antara data prediksi dan data yang nyata, bersama-sama dengan informasi lain digunakan untuk mereproduksi prediksi, dan kemudian dikuantisasi dan kode.

Dalam beberapa sistem kedua teknik digabungkan, dengan mengubah code yang digunakan untuk mengkompresi kesalahan sinyal yang dihasilkan dari tahapan prediksi, adapun rumus metode lossy dalam mengkompress file citra adalah sebagai berikut

$$
\begin{gathered}
\text { NISBAH }=100 \% \\
\left(\frac{\text { ukuran_citra_hasil_kompresi }}{\text { ukuran_citra_semula }}\right) \times 100 \%
\end{gathered}
$$

\subsection{Metode Bit-Plane Complexity \\ Segmentation (BPCS) \\ Bit-plane complexity segmentation} (BPCS) adalah salah satu teknik steganografi yang diperkenalkan oleh Eiji Kawaguchi dan R. O. Eason pada tahun 1997. Teknik ini merupakan teknik steganografi kapasitas besar, karena dapat menampung data rahasia dengan kapasitas yang relatif besar jika dibandingkan dengan metode steganografi lain seperti LSB (Least Significant Bit).

Eiji Kawaguchi dan R. O. Eason memperkenalkan teknik BPCS ini untuk digunakan pada dokumen citra dengan format $B M P$ yang tidak terkompresi. Dokumen citra tersebut dibagi menjadi beberapa segmen dengan ukuran $8 \times 8$ pixel setiap segmennya. Pada dokumen citra 8-bit, setiap satu segmen akan memiliki 8 buah bitplane yang merepresentasikan pixel - pixel dari setiap bit tersebut. Kedelapan bitplane ini disebut $P B C$ system (Pure Binary Coding). Pada BPCS, proses embedding dilakukan pada bit-plane dengan sistem CGC (Canonical Gray Coding) karena proses bit slicing pada CGC cenderung lebih baik dibandingkan pada $P B C$.

Proses penyisipan data dilakukan pada segmen yang memiliki kompleksitas yang tinggi. Segmen yang memiliki kompleksitas tinggi ini disebut noise-like regions. Pada segmen-segmen ini penyisipan dilakukan tidak hanya pada least significant bit, tapi pada seluruh bit-plane. Karena itu kapasitas data pada BPCS dapat mencapai $50 \%$ dari ukuran cover-imagenya. Sumber : Shrikant S. Khaire and DR. Sanjay L. Nalbalwar (2010). "Review: Steganography - Bit Plane Complexity Segmentation (BPCS) Technique." Department of Electronics \& Telecommunication, Dr. Babasaheb Ambedkar Technological University, Lonere, Dist: Raigad, Maharashtra, India. 2(9). 4860-4868.

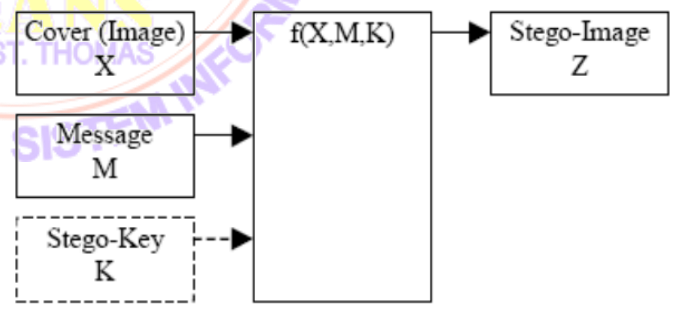

\section{Gambar 7 : Basic digital Steganography Encoder}

Sumber : Shrikant Khaire et. al. / International Journal of Engineering Science and

Technology Vol. 2(9), 2010, 4860-4868

\subsubsection{Kompleksitas Gambar Biner}

Kompleksitas gambar biner adalah suatu parameter kerumitan dari suatu gambar biner. Pada makalah ini, ukuran kompleksitas yang akan digunakan adalah black-and-white border image complexity. Perubahan warna hitam dan putih dalam gambar biner adalah ukuran yang baik untuk menghitung nilai kompleksitas. Jika perubahan warna yang terjadi banyak, maka gambar tersebut memiliki tingkat kompleksitas 
tinggi. Jika sebaliknya, maka gambar tersebut merupakan gambar yang simpel.

Perubahan warna hitam-putih adalah jumlah dari perubahan warna yang terjadi pada setiap baris dan kolom dalam gambar. Sebagai contoh, sebuah pixel hitam yang dikelilingi pixel putih memiliki nilai perubahan warna 4.

Dengan a sebagai nilai kompleksitas, maka rumus penghitungan kompleksitas yang akan digunakan adalah :

$\alpha=\frac{k}{n}$

Dengan $k$ adalah jumlah perubahan warna hitam-putih dan $\mathrm{n}$ adalah kemungkinan maksimal perubahan warna dalam gambar.

\subsubsection{Konjugasi dari Gambar Biner}

Konjugasi dari suatu gambar biner $P$ adalah sebuah gambar biner lainnya yang memiliki nilai kompleksitas sebesar satu 3 . dikurangi nilai kompleksitas P. Dari Gambar 1 dapat dilihat bahwa $\mathrm{P}$ adalah gambar yang memiliki pixel background dengan pola $\mathrm{W}$ dan pixel foreground dengan pola $\mathrm{B}$. $\mathrm{P}^{*}$ yang merupakan konjugasi dari $\mathrm{P}$ memiliki spesifikasi sebagai berikut :

1. Memiliki bentuk area foreground sama dengan $\mathrm{P}$.

2. Memiliki pola area foreground sama dengan pola Bc.

3. Memiliki pola area background sama dengan pola Wc.
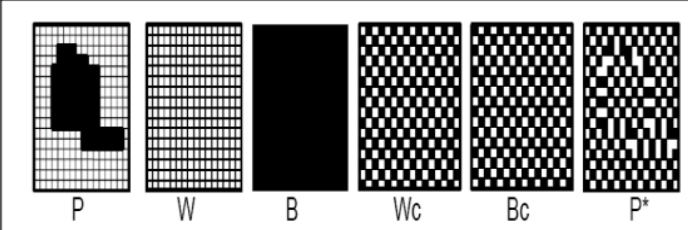

\section{Gambar 8 : Proses Menampilkan Gambar} dengan Warna 24-bit

Sumber : Arya Widyanarko, Implementasi

Steganografi dengan Metode Bit-Plane

Complexity Segmentation (BPCS) untuk Dokumen Citra Terkompresi

Untuk membangun sebuah konjugasi $\mathrm{P}^{*}$ dari sebuah gambar $\mathrm{P}$, dapat dilakukan dengan rumus berikut, dimana " $\oplus$ " menandakan operasi exclusive $O R$.
$\mathrm{P}^{*}=\mathrm{P} \oplus \mathrm{Wc}$
$\left(P^{*}\right)^{*}=P$
$\mathrm{P}^{*} \neq \mathrm{P}$

Jika $\alpha(P)$ adalah kompleksitas dari $P$, maka:

$\alpha\left(P^{*}\right)=1-\alpha(P)$

\subsubsection{Informative Region dan Noise-Like Region}

Informative image berarti gambar yang simpel, sementara noise-like region berarti gambar yang kompleks. Hal ini hanya berlaku pada kasus dimana sebuah gambar biner merupakan bagian dari sebuah gambar yang natural.

Kompleksitas sebuah area bit-plane adalah parameter yang digunakan dalam menentukan sebuah bit-plane merupakan informative atau noise-like region. Parameter kompleksitas ini dibatasi oleh nilai threshold $(\alpha 0)$.

Sebuah bit-plane tergolong sebagai informative region apabila memiliki nilai kompleksitas yang lebih kecil dibandingkan threshold $(\alpha \leq \alpha 0)$ dan sebaliknya akan dianggap sebagai noise-like region. Pada tugas akhir ini, nilai $\alpha 0$ yang digunakan beragam, yaitu diantara 0,1 hingga 0,5 .

\section{PEMBAHASAN}

3.1. Analisis Kecocokan Teknik
Complexity Segmentation
Citra
Terkompresi dengan PNG
Portable Network Graphics merupakan format yang paling terakhir dikembangkan dibandingkan GIF dan JPEG. Pengembangannya ditujukan untuk dapat menggantikan peranan format GIF. Kedua format ini memang memiliki ciri yang cukup mirip, namun PNG telah jauh lebih berkembang dengan penggunaan jenis pewarnaan yang lebih beragam.

Format PNG secara umum digunakan untuk citra web karena dapat menampung pixel dengan warna $R G B 24$ dan 48 bit, grayscale 8 dan 16 bit serta indexed color dengan kedalaman piksel 1 hingga 8 bit. Penerapan BPCS pada format ini tentunya tidak akan memiliki masalah besar dilihat dari aspek pengubahan gambar sebelum dan sesudah penyisipan karena mendukung penggunaan warna $R G B$.

Kemungkinan terbaik pada penerapan $B P C S$ ini adalah jika cover image $P N G$ menggunakan warna $R G B$ atau grayscale, bukan indexed color. Jika hal tersebut terjadi, maka tidak ada masalah pada penyisipan yang dilakukan. Kemungkinan terburuk adalah jika tabel warna Digunakan yang menandakan bahwa cover image merupakan citra PNG dengan indexed color yang memiliki banyak warna yang sangat berbeda-beda. Jika citra tersebut yang Digunakan sebagai perantara, maka cukup besar kemungkinan bahwa stegoimage hasil penyisipan berubah cukup drastis.

Kemungkinan tersebut hanya berkaitan dengan hasil keluaran proses penyisipan yang dikhawatirkan berupa gambar yang rusak. Kemungkinan hilang atau rusaknya pesan 
rahasia tidak ada pada penerapan BPCS pada $P N G$. Hal tersebut cukup jelas mengingat teknik kompresi yang Digunakan pada PNG merupakan kompresi yang lossless.

Seperti kedua format yang telah dibahas sebelumnya, teknik BPCS pun tidak benarbenar berjalan dengan sempurna pada penerapan penyisipan pada dokumen citra $P N G$. Kemungkinan rusaknya citra perantara pesan rahasia tetap terbuka walaupun tidak terbuka lebar.

Dengan demikian, maka BPCS dapat diterapkan dengan baik pada citra digital dengan format PNG tanpa adanya kerusakan pesan dan hanya kemungkinan kecil menghasilkan stego-image yang agak terlihat rusak jika menggunakan indexed color. Format ini cocok dengan teknik BPCS.

\section{Tabel 1 : Perbandingan Kecocokan BPCS dengan JPEG dan PNG}

\begin{tabular}{|c|c|c|c|}
\hline ASPEK & JPEG & GIF & PNG \\
\hline $\begin{array}{c}\text { Ada bit yang hilang pada saat } \\
\text { kompresi }\end{array}$ & Ya & Tidak & Tidak \\
\hline $\begin{array}{c}\text { Pesan rahasia terjaga tanpa } \\
\text { ada kerusakan }\end{array}$ & Tidak & Ya & Ya \\
\hline $\begin{array}{c}\text { Mendukung RGB atau } \\
\text { indexed color }\end{array}$ & $R G B$ & $\begin{array}{c}\text { Indexe } \\
d \text { color }\end{array}$ & Keduanya \\
\hline $\begin{array}{c}\text { Kecocokan dengan BPCS ( } \\
\text { skala 0-5) }\end{array}$ & 4 & 2,5 & 4,5 \\
\hline
\end{tabular}

Tabel 1. menunjukkan perbandingan kecocokan ketiga format citra terkompresi yang dianalisis dengan BPCS. Format PNG merupakan format yang paling cocok dengan BPCS.

\subsection{Analisis Algoritma BPCS}

Berikut adalah langkah-langkah yang dilakukan pada algoritma BPCS saat menyisipkan data :

1. Mengubah cover image dari sistem $P B C$ menjadi sistem CGC. Sebelumnya, gambar tersebut di-slice terlebih dahulu menjadi bit-plane. Setiap bit-plane mewakili bit dari setiap pixel. Gambar 9 menunjukkan proses pemotongan gambar menjadi kumpulan bit-plane.

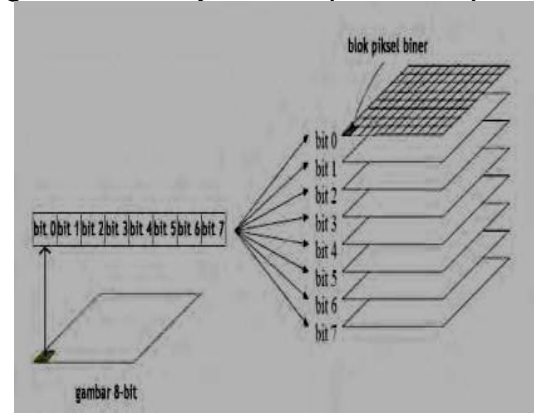

Gambar 9 : Bit-Slicing pada Gambar 8-bit
Jika dilihat dari gambar 9, maka bit-plane yang disusun oleh bit 7 merupakan least significant bit. Pada BPCS, semua bit-plane memiliki kemungkinan untuk diganti, tidak hanya least significant bit. Bit-plane yang berupa gambar biner tersebut dikonversi dari $P B C$ menjadi CGC. Gambar 12 menunjukkan perbedaan pada $P B C$ dan $C G C$.

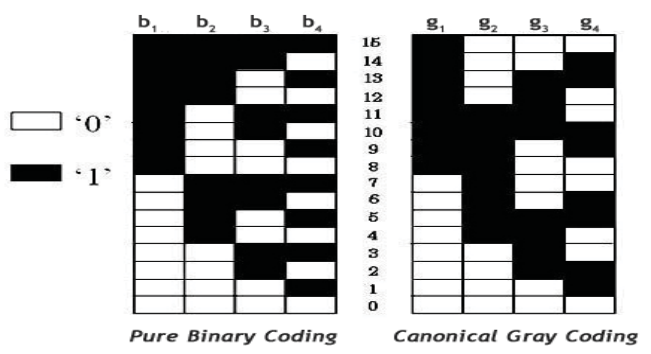

\section{Gambar 10 : Gambar Biner Dengan PBC dan CGC}

2. Segmentasi setiap bit-plane pada cover image menjadi informative dan noise like region dengan menggunakan nilai batas/threshold (_0). Nilai umum dari $0=0,4$.

3. Bagi setiap byte pada data rahasia menjadi blok-blok

4. Jika blok $(S)$ tidak lebih kompleks dibandingkan dengan nilai batas, maka lakukan konjugasi terhadap $S$ untuk mendapatkan $S^{*}$ yang lebih kompleks.

5. Sisipkan setiap blok data rahasia ke bitplane yang merupakan noise-like region (atau gantikan semua bit pada noise-like region). Jika blok $S$ dikonjugasi, maka simpan data pada "conjugation map".

6. Thisipkan juga pemetaan konjugasi yang telah dibuat

7. UlSah stego-image dari sistem CGC menjadi sistem $P B C$

8. Proses ekstraksi data rahasia dapat dilakukan dengan menerapkan langkahlangkah penyisipan secara terbalik. Sebagai contoh, sebuah dokumen citra akan disisipi sebuah pesan rahasia Ms. Pertama-tama pixel pada citra tersebut (cover image) dibagi menjadi segmensegmen gambar biner seperti ditunjukkan pada gambar 2.9. Kemudian pesan rahasia dibagi menjadi blok yang masing-masing berukuran 64 bit, dan direpresentasikan pada matriks berukuran $8 \times 8$.

Dari langkah tersebut, hasilnya kita mendapatkan stego-object. Lalu cara mengekstrak informasinya adalah dengan:

1. Ubah stego-object dari representasi $P B C$ ke CGC 
2. Tentukan segmen mana yang informatif dan segmen mana yang noise-like dengan threshold yang sama dengan threshold ketika proses embedding. Dengan kata lain nilai Ukuran berkas original adalah 944,408 byte. Ternyata BPCS mampu menampung berkas berukuran 441,418 byte dalam cover-object. Dengan kata lain kapasitas penyimpanannya mencapai $40 \%$ lebih. Selain itu jika kita hitung lagi bahwa data yang ditanam adalah hasil kompresi dari ukuran 1,212,744 byte, hasil steganografi ini terasa menakjubkan. Lebih baik lagi jika hasil stego-object dikompresi dengan kompresi yang lossless. Pada simulasi ini, kompresi dilakukan sampai stego-object berukuran 505,502 byte. Dengan kata lain data yang disimpan dalam stego-object berukuran 505,502 byte ini adalah sebanyak data embedded message yang belum dikompresi yaitu sebesar 1,212,744 byte. Pesan yang disimpan mencapain $2.5 x$ ukuran stego-object.

Algoritma untuk decoding hanyalah prosedur kebalikan dari langkah memasukkan kode. Inovasi steganography BPCS adalah sebagai berikut:

1. Pembagian tiap bit-plane dari gambar berwarna ke dalam daerah "informative" dan "noise like"

2. Pengenalan batas BW (black - white) berdasarkan pengukuran kompleksitas (a) untuk pembagian daerah.

3. Pengenalan operasi konjugasi untuk mengubah blok rahasia sederhana menjadi blok yang kompleks.

4. Menggunakan image plane CGC dan bukan image plane $P B C$.

Metode steganography BPCS memiliki beberapa parameter untuk penerapan program praktis. Berapa di antaranya adalah :

1. Lokasi header dari file rahasia

2. Parameter enkripsi dari file rahasia

3. Parameter kompresi dari file rahasia.
Untuk mengetahui bagaimana proses metode lossy dalam mengkompress file citra atau gambar, berikut adalah analisanya disertakan dengan sampel gambar yang akan di proses.

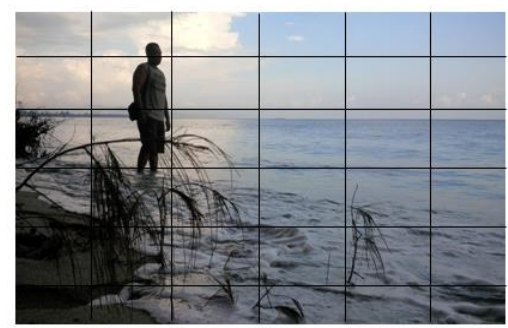

\section{Gambar 11 : Citra Sebelum Di Kompresi}

\section{Contoh:}

Misalnya sebuah citra dengan memiliki image size ukuran $6 \times 6$ pixel dengan 8 derajat $R, 8$ derajat $G$ dan 8 derajat $B$ sebagai berikut:

$\begin{array}{lll}\text { Matrik R: } & \text { Matrik G: } & \text { Matrik B: } \\ 113712 & 446122 & 777551 \\ 446122 & 777551 & 644422 \\ 777551 & 644422 & 552221 \\ 644422 & 552221 & 223300 \\ 552221 & 223300 & 113712 \\ 223300 & 113712 & 446122\end{array}$

Tabel 2 : Penggabungan Matriks RGB sebelum dikompres

\begin{tabular}{|c|c|c|c|c|c|}
\hline RGB & RGB & RGB & RGB & RGB & RGB \\
\hline 147 & 147 & 367 & 715 & 125 & 251 \\
\hline 476 & 474 & 674 & 154 & 254 & 252 \\
\hline 765 & 745 & 742 & 542 & 522 & 121 \\
\hline 652 & 452 & 423 & 423 & 220 & 210 \\
\hline 521 & 521 & 233 & 233 & 201 & 112 \\
\hline 214 & 214 & 336 & 371 & 012 & 022 \\
\hline
\end{tabular}

Dan dapat diturunkan kedalam bilangan Biner sebagai berikut:

\subsection{Analisa Metode Lossy}

Tabel 3 : Matrik RGB Sebelum dikompres

\begin{tabular}{|c|c|c|c|c|c|}
\hline $\begin{array}{lcc}1 & 4 & 7 \\
001 & 100 & 111\end{array}$ & $\begin{array}{l}147 \\
001100111\end{array}$ & $\begin{array}{lccc}3 & 6 & 7 & \\
011 & 11 & 111\end{array}$ & $\begin{array}{llll}7 & 1 & 5 & \\
111 & 001 & 101\end{array}$ & $\begin{array}{llll}1 & 2 & 5 & \\
001 & 010 & 101\end{array}$ & 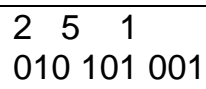 \\
\hline $\begin{array}{l}476 \\
100111110\end{array}$ & $\begin{array}{lll}4 & 7 & 4 \\
100 & 111 & 100\end{array}$ & $\begin{array}{lcc}6 & 7 & 4 \\
110 & 111 & 100\end{array}$ & $\begin{array}{l}1 \quad 54 \\
001101100\end{array}$ & $\begin{array}{lccc}2 & 5 & 4 & \\
010 & 101 & 100\end{array}$ & 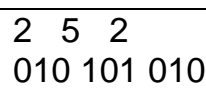 \\
\hline $\begin{array}{llll}7 & 6 & 5 \\
111 & 110 & 101 \\
\end{array}$ & $\begin{array}{llll}7 & 4 & 5 \\
111 & 100 & 101 \\
\end{array}$ & $\begin{array}{llll}7 & 4 & 2 \\
111 & 100 & 010 \\
\end{array}$ & $\begin{array}{llll}5 & 4 & 2 \\
101 & 100 & 010\end{array}$ & $\begin{array}{lll}5 & 2 & 2 \\
101 & 010010\end{array}$ & $\begin{array}{lll} & 2 & 1 \\
001 & 010001\end{array}$ \\
\hline $\begin{array}{llll}6 & 5 & 2 \\
110 & 101010 \\
\end{array}$ & $\begin{array}{lll}4 & 5 & 2 \\
100 & 101010\end{array}$ & $\begin{array}{lll}4 & 2 & 3 \\
100 & 010011\end{array}$ & $\begin{array}{lll}4 & 2 & 3 \\
100 & 010011\end{array}$ & $\begin{array}{llll}2 & 2 & 0 \\
010 & 010000\end{array}$ & $\begin{array}{llll}2 & 1 & 0 \\
010 & 001010\end{array}$ \\
\hline $\begin{array}{llll}5 & 2 & 1 \\
101 & 010001\end{array}$ & $\begin{array}{lll}5 & 2 & 1 \\
101 & 010001\end{array}$ & $\begin{array}{lll}2 & 3 & 3 \\
010 & 011 & 001\end{array}$ & $\begin{array}{llll}2 & 3 & 3 \\
010 & 011 & 011 \\
\end{array}$ & $\begin{array}{llll}2 & 0 & 1 \\
010 & 000 & 001 \\
\end{array}$ & $\begin{array}{llll}1 & 1 & 2 \\
001 & 001 & 010 \\
\end{array}$ \\
\hline $\begin{array}{lllll}2 & 1 & 4 & \\
010 & 001 & 100 \\
\end{array}$ & $\begin{array}{llll}2 & 1 & 4 & \\
010 & 001 & 100\end{array}$ & $\begin{array}{ccc}3 & 3 & 6 \\
011 & 011 & 110 \\
\end{array}$ & $\begin{array}{lllll}3 & 7 & 1 & \\
0 & 7 & 1 & 111 & 001\end{array}$ & $\begin{array}{lcc}0 & 1 & 2 \\
000 & 001 & 010 \\
\end{array}$ & $\begin{array}{lll}0 & 2 & 2 \\
000 & 010 & 010\end{array}$ \\
\hline
\end{tabular}


Yang akan dikompres menjadi citra dengan 4 derajat keabuan (0 s/d 3), jadi setiap derajat keabuan direpresentasekan dengan 2 bit. Adapun langkah-langkah untuk mengkompres dengan menggunakan metode lossy yaitu:

1. Langkah I: Buat Histogram citra semula Histogram citra semula untuk menghasilkan nilai matriks

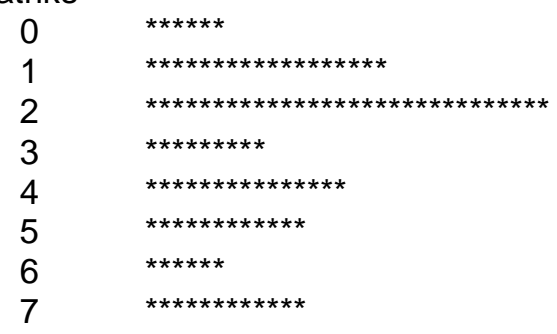

Ada 108 pixel, dikelompokkan menjadi 4 kelompok derajat RGB. tiap kelompok ada sebanyak rata-rata $108 / 4=27$ pixel perkelompok.

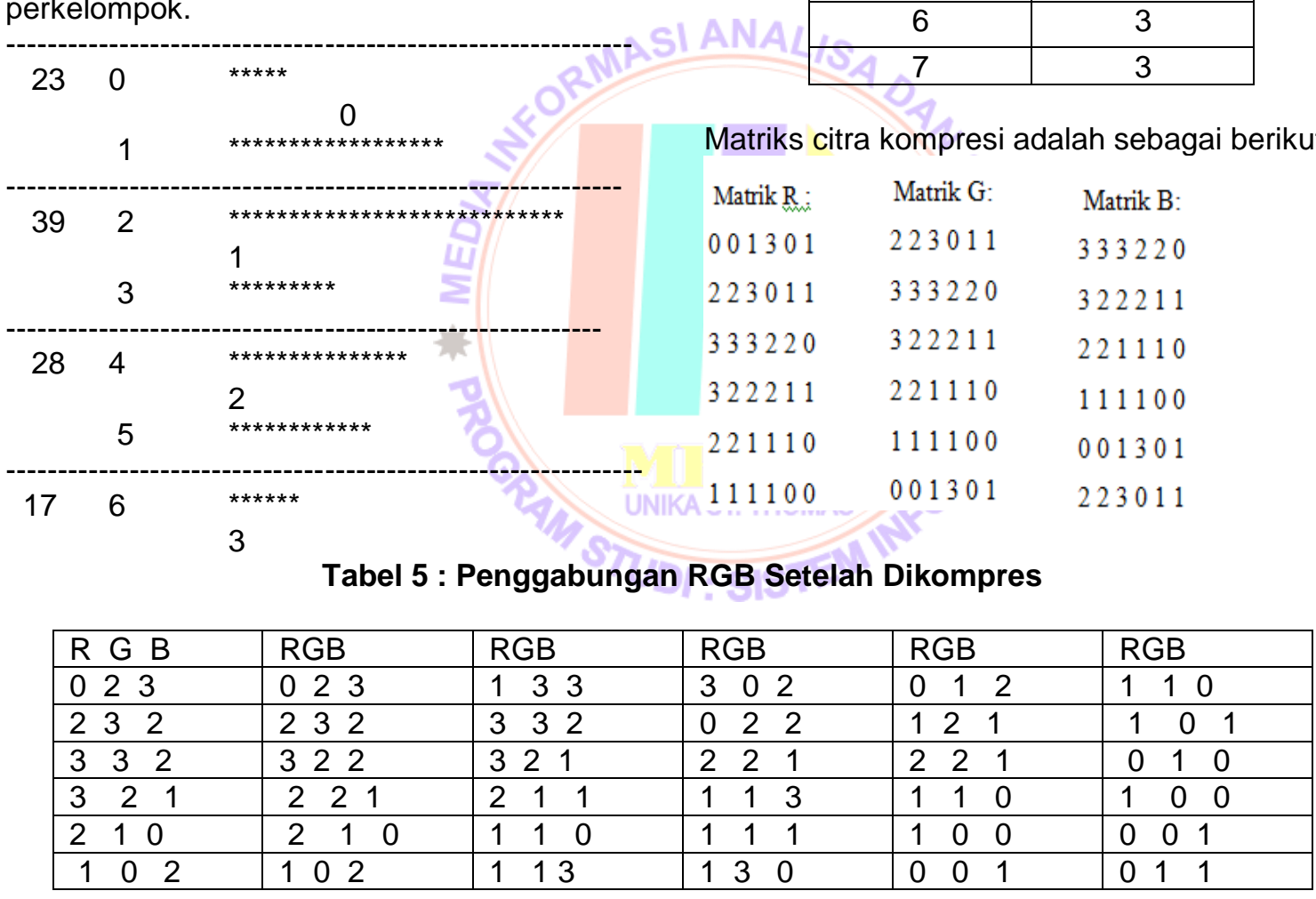

Dan penggabuangan RGB dapat diturunkan kedalam Biner sebagai berikut:

Tabel Bilangan Biner 6 : Matrik RGB Sebelum dikompres

\begin{tabular}{|c|c|c|c|c|c|}
\hline $\begin{array}{lll}0 & 2 & 3 \\
000 & 010 & 011\end{array}$ & $\begin{array}{lll}0 & 2 & 3 \\
000 & 010 & 011\end{array}$ & $\begin{array}{lll}1 & 3 & 3 \\
001 & 001 & 011\end{array}$ & $\begin{array}{lll}3 & 0 & 2 \\
011 & 000 & 010\end{array}$ & $\begin{array}{lcc}0 & 1 & 2 \\
000 & 001 & 012\end{array}$ & $\begin{array}{lll}1 & 1 & 0 \\
001 & 001000\end{array}$ \\
\hline $\begin{array}{lcc}2 & 3 & 2 \\
010 & 011 & 010\end{array}$ & $\begin{array}{lll}2 & 3 & 2 \\
010 & 001 & 010\end{array}$ & $\begin{array}{lccc}3 & 3 & 2 & \\
011 & 011 & 001 \\
010 & & \end{array}$ & $\begin{array}{lll}0 & 2 & 2 \\
000 & 010 & 010\end{array}$ & $\begin{array}{lcc}1 & 2 & 1 \\
001 & 012001\end{array}$ & $\begin{array}{lll}1 & 0 & 1 \\
001 & 000 & 001\end{array}$ \\
\hline $\begin{array}{llll}3 & 3 & 2 & \\
011 & 001 & 010\end{array}$ & $\begin{array}{lll}3 & 2 & 2 \\
011 & 001 & 010\end{array}$ & $\begin{array}{lrr}3 & 2 & 1 \\
011 & 001 & 001\end{array}$ & $\begin{array}{l}2 \quad 2 \quad 1 \\
001010001\end{array}$ & $\begin{array}{lcc}2 & 2 & 1 \\
001 & 010001\end{array}$ & $\begin{array}{lll}0 & 1 & 0 \\
000 & 001 & 000\end{array}$ \\
\hline
\end{tabular}




\begin{tabular}{|c|c|c|c|c|c|}
\hline $\begin{array}{lcc}3 & 2 & 1 \\
011 & 001001\end{array}$ & $\begin{array}{l}2 \quad 21 \\
001010001\end{array}$ & $\begin{array}{lll}2 & 1 & 1 \\
010 & 001001\end{array}$ & $\begin{array}{lll}1 & 1 & 3 \\
001 & 011 & 011\end{array}$ & $\begin{array}{lll}1 & 1 & 0 \\
001 & 001000\end{array}$ & $\begin{array}{lll}1 & 0 & 0 \\
001 & 000 & 000\end{array}$ \\
\hline $\begin{array}{lll}2 & 1 & 0 \\
001 & 001000\end{array}$ & $\begin{array}{lll}2 & 1 & 0 \\
001 & 001000\end{array}$ & $\begin{array}{lll}1 & 1 & 0 \\
001 & 001000\end{array}$ & $\begin{array}{ccc}1 & 1 & 1 \\
001 & 001 & 001 \\
\end{array}$ & $\begin{array}{lll}1 & 0 & 0 \\
001 & 000 & 000\end{array}$ & $\begin{array}{llll}0 & 0 & 1 \\
000 & 000 & 001\end{array}$ \\
\hline $\begin{array}{cccc}1 & 0 & 2 & \\
001 & 000 & 001\end{array}$ & $\begin{array}{llll}1 & 0 & 2 \\
001 & 000 & 001\end{array}$ & $\begin{array}{l}113 \\
001001011\end{array}$ & $\begin{array}{llll}1 & 3 & 0 & \\
001 & 011 & 000\end{array}$ & $\begin{array}{llll}0 & 0 & 1 \\
000 & 000 & 001\end{array}$ & $\begin{array}{lllll}0 & 1 & 1 & \\
000 & 001 & 001\end{array}$ \\
\hline
\end{tabular}

Dengan representasi matriks di atas dapat dilihat bahwa banyak pixel lama yang terbuang digantikan dengan pixel asli, sehingga menyebabkan kualitas gambar sedikit berkurang, tetapi perubahan ini tidak tampak kasat mata, berikut adalah hasil kompresi citranya.

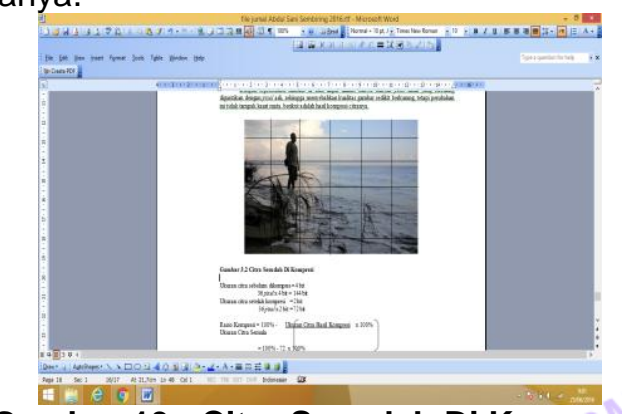

Gambar 13 : Citra Sesudah Di Kompresi

Ukuran citra sebelum dikompres $=4$ bit 36 pixel $\times 4$ bit $=144$ bit

Ukuran citra setelah kompresi $=2$ bit 36 pixel $\times 2$ bit $=72$ bit Rasio Kompresi $=100 \%-($ Ukuran Citra Hasi)
Kompresi $\times 100 \%$

Ukuran Citra Semula

$$
=100 \%-\frac{72}{144} \times 100 \%
$$$$
=50 \% \text {, yang artinya } 50 \% \text { dari }
$$

citra semula telah dikompres.

\section{KESIMPULAN}

1. Kapasitas hasil steganografi ( format PNG) akan lebih besar beberapa kali dari gambar awal yang ber-format JPG

2. Kapasitas hasil steganografi ( format PNG ) akan sama dari gambar awal yang berformat PNG.

3. Steganografi dengan metode BPCS dapat diterapkan pada citra terkompresitanpa adanya modifikasi pada proses utama penyisipan dan ekstraksi pesan

4. Tingkat hasil kompresi dengan menggunakan Metode Lossy tergantung pada format file gambar yang dikompres.

5. Perangkat lunak ini dapat menampilkan hasil kompresi berupa ukuran awal dan ukuran sesudah dikompresi.
[1]. Abdul Sani Sembiring, "Analisis Steganografi Pada Citra Terkompresi Dengan Metode Bit-Plane Complexity Segmentation (BPCS), Cemerlang 0216 - 3535, Vol 12/1-117/NOP-DES 2011

[2]. Eiji Kawaguchi and Richard O. Eason. "Principle and applications of BPCSSteganography", Kyushu Institute of Technology, Kitakyushu, Japan and University of Maine, Orono, Maine 04469-5708.

[3]. Shrikant S. Khaire and DR. Sanjay L. Nalbalwar (2010). "Review: Steganography - Bit Plane Complexity Segmentation (BPCS) Technique", Department of Electronics \& Telecommunication, Dr. Babasaheb Ambedkar Technological University, Lonere, Dist: Raigad, Maharashtra, India. 2(9). 4860-4868.

[4]. Sherin Jabbar and Shaiju Panchikkil. "Lossy Compression Schemes Based On Transforms-A Literature Review On Medical Images", Department of Computer Engineering, MES Engineering College, Kuttippuram, Kerala, International Journal of Advanced Information Technology (IJAIT) Vol. 2, No.6, December 2012

[5]. Mulyanto Edy, S.Si., M.Kom. (2009), Teori Pengolahan Citra", Jogjakarta : Penerbit Andi.

[6]. Miano and John (1999). "Compressed Image File Format JPEG, PNG, GIF, XBM, BMP" Addison Wesley Longman, Inc.

[7]. Negnevitsky Michael (2002), "Artificial Intelligence : A Guide to Intelligence System", Enggland: Addison-Wesley.

[8]. Dony Ariyus (2006),"Computer Security",Yogyakarta :Andi Offset.

[9]. http://color-meclub.deviantart.com/art/Zebra-lineart99491504

[10]. http://www.eclipse.org/articles/Article-UIGuidelines/Index.html

[11]. http://www.infofotografi.com/blog/2014/06 /dynamic-range-bit-depth-dan-colordepth-dalam-sensor-kamera-digital/

\section{DAFTAR PUSTAKA}

